\title{
`Kandungan Protein dan Abu Tanaman Alfalfa( Medicago sativa L) setelah Pemupukan Biorisa
}

\author{
Sarjana Parman \\ Laboratorium Struktur dan Fungsi Tumbuhan, Jurusan Biologi FMIPA Undip
}

\begin{abstract}
The reasearch is about protein and ash content in Alfalfa ( M.sativa L ) after fertilization bioriza-02. This research is in polibag plastic in 15 March-15 August 2006, using to research design RAL ( Randomized Complete Design ), Treatmen is give fertilization biorisa-02 , one treatment is Po ( without biorisa ) P1 (Biorisa-02 0,5 caps/ plant ), P2 (1 caps/plant); P3;(11/2 caps/plant) and P4 (2 caps / plant) every treatment repeated five times . Protein conternt and ash analysed follow of makro-Kjeldahl which modification (AOC, 1970 in Sudarmaji, 1984). The result of research indicated that increase of dose of fertilization biorisa- 02 will boost up rate of protein of crop alfalfa, though fertilization of dose Po (without biorisa-02 caps/plant) 18,472 mg/100 of gram differ is not real by control 18.264; so also fertilization 1 caps/plant ( 20,786 ) differing is not real with fertilization have dose $(20,82)$ but differ reality with gift fertilize to have dose $2 \mathrm{mg} /$ plant $(21,828)$
\end{abstract}

Key words : Alfalfa, protein, Abu, biorisa

Penelitian tentang kandungan protein dan abu pada alfalfa (M,sativa L ) setelah pemupukan biorisa-02 telah dilakukan. Penelitian dilakukan menggunakan plastik polibag mulai 15 maret-15 agustus 2006 menggunakan disain RAL (Randomized complete Design). Perlakuan berupa pemberian pupuk biorisa-02, satu perlakuan yaitu Po (tanpa biorisa); P1 (0,5 kapsul/tanaman); P2 (1 kapsul/tanaman); P3 (1,5 kapsul/tanaman); dan P4 ( (2 kapsul/tanaman). Masing-masing perlakuan diulang 5 kali. Kandungan protein dan abu dianalisis dengan makroKjeldahl yang mengikuti modifikasi (AOC, 1970 dalam Sudarmaji 1984). Hasil penelitian menunjukkan kenaikan pupuk biorisa akan menaikkan protein tanaman alfalfa, dimana pemupukan Po (tanpa biorisa-02 kapsul/tanaman) $18,472 \mathrm{mg} / 1000$ gram berbeda tidak nyata dengan kontrol 18,264; pemupukan $1 \mathrm{kapsul} / \operatorname{tanaman}(20,786)$ berbeda tidak nyata dengan kontrol 18,264), berbeda tidak nyata $(20,82)$ namun berbeda nyata dengan pemupukan berdosis $2 \mathrm{mg} / \operatorname{taaman}(21,828)$

Kata kunci : Alfalfa, protein, Abu, biorisa

\section{PENDAHULUAN}

Tumbuhan alfalfa (Medicago sativa L) merupakan tanaman hutan liar yang tertua. tumbuh di pegunungan Mediterania di sebelah barat daya Asia. Tumbuhan ini diperkenalkan ke Eropa dari Asia oleh bangsa Persia pada perkiraan abad tahun 490 SM. Habitat asli dari Alfalfa (Medicago sativa L) adalah daerah sub tropis. Dalam perkembangannnya Alfalfa dibudidayakan di Amerika Serikat, Jepang, Australia, Korea untuk memenuhi kebutuhan hijauan bagi ternak sapi, baik sapi perah maupun sapi potong dan juga ruminansia yang lain. Kekurangan hijauan pada ternak terutama Ruminansia akan mengakibatkan penurunan produksi baik susu maupun daging hewan tersebut. (Anonim-a, 2004). Alfalfa merupakan rumput yang digolongkan dalam famili Leguminosae dan ditandai dengan adanya bintilbintil akar akibat asosiasi dengan bakteri Rhizobium sehingga mampu mengfiksasi nitrogen atmosfer secara efektif.

Protein merupakan sebagian besar menu makanan manusia dan kebutuhan protein manusia hampir semuanya berasal dari protein biji, khususnya dari tanaman serealia seperti padi, gandum dan jagung (Salisbury \& Ross, 1992). Sumbangan yang kecil tapi penting juga diberikan pada biji tanaman kacang kacangan 
(Leguminosae)

seperti kacang buncis, kacang kapri dan kedelai. Kedelai mengandung protein yang tinggi dan seimbang dimana mencapai sekitar 40 $\%$ nya adalah protein, sementara di dalam biji tanaman serealia hanya $12 \%$ (Salisbury \& Ross, 1992).

Sari beberapa penelitian, protein yang terdapat dalam biji serealia ternyata rendah kandungan lisinnya, sedang di dalam biji kacangkacangan rendah kandungan metionin ; sedangkan di dalam biji buncis hanya mengandung metionin $1,0 \%$. Protein terdiri dari serangkaian asam amino yang terangkai dalam urutan yang khas dan biasanya urutan asam amino ini akan menentukan aktivitas biologi suatu protein (Cech \& Bass, 1986)

Fungsi Protein di dalam kehidupan biologi makhluk hidup terutama tumbuhan antara lain adalah mengkatalisis suatu proses reaksi ; sebagai ensim misal protein mikrotubul dan protein mikrofilamen ( aktin ) serta beberapa protein yang ada di ribosom yang mempunyai fungsi struktural dan bukan fungsi katalisis; protein pengangkut elektron selama selama fotosintesis dan respirasi; sebagai cadangan makanan yaitu sebagai cadangan asam amino untuk bibit setelah berkecambahan berlangsung (Cech \& Bass, 1986). Struktur protein terdiri dari satu atau lebih rantai polipeptida yang masing-masing terdiri dari ratusan asam amino, komposisi dan ukuran tiap protein tergantung dari jenis dan jumlah sub unit asam amino; namun sebagian besar protein tumbuhan mempunyai obot molekul lebih dari 40.000 Daltons, misal protein feredoksin yang terlibat dalam fotosintesis.

Alfalfa dalam bahasa ilmiah disebut Medicago sativa L berasal dari Negara subtropis yakni Canada, Australia, dan beberapa negara lain dibelahan bumi bagian Barat. Nama alfalfa berasal dari bahasa Arab yang artinya bapak dari segala tanaman. Di negara asalnya tanaman ini dibudidayakan untuk memenuhi konsumsi ternak ruminansia, sehingga ternak luar negeri sapi, domba mempunyai bentuk tubuh yang menarik sehat dan gemuk (Anonim-b; Anonim-c)

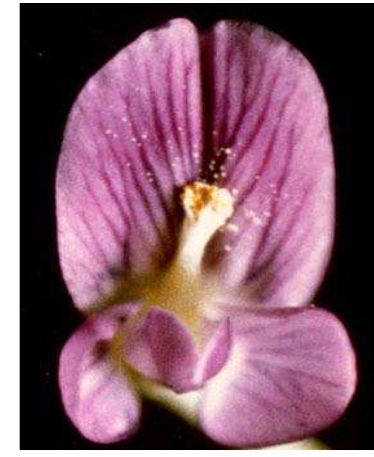

Gambar. A Keterangan :

A. Bunga tanaman Alfalfa (M. sativa $\mathrm{L}$ )

B. Tanaman Alfalfa ( M. Sativa $L$ )

Tanaman alfalfa (Medicago sativa L) termasuk golongan famili Leguminosae atau familia fagaceae dan ditandai dengan adanya bintil-bintil akar akibat asosiasi dengan bakteri Rhizobium sp sehingga mampu memfiksasi nitrogen atmosfer secara efektif. Hasil penelitian di luar negeri telah berhasil membuktikan berbagai zat yang terkandung didalam tanaman alfalfa tersebut. Kandungan protein yang tinggi dan klorofl tinggi, sampai empat kali lipat dibandingkan dengan tanaman sayuran yang lain, sehingga sangat bermanfaat untuk meningkatkan kesehatan manusia dan hewan ternak. Daun tanaman alfalfa banyak mengandung saponin, coumestrol, vitamin, mineral, antioksidan Kandungan protein dan serat yang tinggi sangat cocok digunakan sebagai hijauan bagi ternak sapi atau ruminansia, bahkan juga baik bagi manusia (Layla.2005).. Tanaman alfalfa menurut Stochmal dkk. (2001) mengandung sembilan macam flavonoid, dan apigenin. glikosida luteolin glycosida dan adenosine. Salah satu pemanfaatan alfalfa. diantaranya tanaman ini dapat dibuat sebagai minuman suplemen dengan nama Liquid Chlorophyll, soft capsul, minuman penyegar yang diproduksi oleh beberapa pabrik farmasi yang cukup terkenal di dunia.

Pupuk Biorisa merupakan pupuk hayati yng diproses secara bioteknologi untuk menunjang kehidupan berwawasan lingkungan. Pupuk Biorisa $02 \mathrm{~K}$ ini dapat digunakan untuk berbagai jenis tanaman hortikultura, perkebunan dan kehutanan. Menurut Anonim-a ( 2006 ) 
Kandungan biorisa 02 terdiri dari cendawan mikorisa merupakan salah satu mikrorganisme yang mampu berasosiasi dengan sebagian besar tumbuh-tumbuhan. Infeksi mikorisa sebagian besar ditemukan pada akar-akar halus tumbuhan (Hyman, 1975). Berdasarkan struktur tubuh dan cara infeksinya terhadap tanaman inang, mikorisa dapat digolongkan menjadi dua kelompok (tipe) yaitu ektomikorisa dan endomikorisa. Pada ektomikorisa, jaringan hifa cendawan tidak sampai masuk ke dalam sel akar bagian dalam tetapi berkembang diantara sel kortek akar membentuk "harting net" dan mantel di permukaan akar. Sedangkan endomikorisa, jaringan hifa cendawan masuk ke dalam sel kortek akar dan membentuk struktur yang khas berbentuk oval yang disebut vesicle dan sistem percabangan hifa yang disebut arbuscle, sehingga endomikorisa disebut juga vesicular-arbuscular micorhizae (VAM) Jamur tersebut hidup di dalam sel-sel akar (intraseluler) dan membentuk hubungan langsung antara sel-sel akar dengan tanah (Mosse, 1981,Rao, 1994; Subiksa, 2002).

Mengingat kandungan biorisa $02 \mathrm{~K}$ dan manfaat tanaman Medicago sativa $\mathrm{L}$ ini maka dalam penelitian ini akan dicobakan apakah ada pengaruh perbedaan pemberian pupuk terhadap kadar protein tanaman alfalfa (Medicago sativa $\mathrm{L}$ ) yang ditanam di kebun percobaan FMIPA Biologi UNNES Semarang.

\section{BAHAN DAN METODE}

Penelitian kandungan protein dan abu tanaman alfalfa (Medicago sativa L ) akibat pemupukan biorisa dilakukan di kebun percobaan laboratorium Jurusan Biologi FMIPA UNNES Sekaran Semarang mulai tanggal 15 Maret -15 Agustus 2006. Disain penelitian digunakan rancangan acak lengkap (RAL) satu perlakuan yaitu pemberian pupuk biorisa dengan 5 tarap dosis pemupukan biokorisa yaitu Mo (tanpa pemupukan), M1 (biorisa 0,5 tablet/polibag), M2 (biorisa 1 tablet/polibag ), M3 (biorisa 1,5 tablet/polibag) dan M4 ( biorisa 2 tablet/polibag). Masing-masing taraf perlakuan terdiri dari 5 ulangan.. Data yang diperoleh dari penelitian ini kemudian dianalisis dengan bantuan program SPSS- 13.

\section{A. Penanaman}

Mula-mula dipilih biji alfalfa yang diperoleh dari IAC (Indonesia Alfata Center) Semarang dan dikecambahkan di dalam polibag berukuran diameter yang berkapasitas $\pm 5 \mathrm{~kg}$ tanah sampai tumbuh dengan baik kira-kira berumur 14 hari dari tanam. Perlakuan pemberian biorizza sesuai percobaan dengan cara ditaburkan disekitar tumbuhan yang sudah tumbuh baik. Penyiraman dilakukan pada tanaman apabila tidak turun hujan dengan air kira-kira sampai tanah di dalam polibag penelitian cukup basah. Penelitian diakhiri setelah tanaman berumur 45 hari. Pada saat tanaman berumur 45 hari dilakukan pemanenan dengan cara memotong seluruh bagian tanaman yang berada di atas tanah baik yang berupa daun maupun batang tanaman untuk kemudian dilakukan analisis kadar protein dan abu tanaman.

\section{B. Analisis protein tanaman alfalfa}

Analisis protein tanaman alfalfa ( $M$. sativa L ) dilakukan mengikuti analisis protein total dengan cara makro-Kjeldahl yang dimodifikasi (AOC, 1970 dalam Sudarmaji, 1984) dan Harborne(1987). Mula-mula ditimbang 1 gr bahan sampel dihaluskan dan dimasukkan kedalam labu Kjeldahl dan ditambahkan 7,5 g $\mathrm{K}_{2} \mathrm{~S}_{2} \mathrm{O}_{4}$ serta $0,35 \mathrm{~g} \mathrm{Hg} \mathrm{O}$ dan $15 \mathrm{ml} \mathrm{H}_{2} \mathrm{SO}_{4}$ pekat. Setelah itu labu dipanaskan dalam almari asam sampai asap yang keluar terhenti. Setalah pemanasan diteruskan dengan api besar sampai mendidih dan cairan menjadi jernih. Setelah cairan menjadi jernih pemanasan diteruskan, dan tambahkan lama pemanasan kira-kira sampai 1 jam. Matikan api pemanas dan bahan dibiarkan menjadi dingin. Setelah dingin tambahkan $100 \mathrm{ml}$ akuades ke dalam labu Kjelhdhl dan didinginkan dalam air es dan beberapa lempeng $\mathrm{Zn}$. Selin itu juga tambahkan $15 \mathrm{ml}$ larutan $\mathrm{K}_{2} \mathrm{C}_{2} \mathrm{O}_{4} 4 \%$ dalam air dan tambahkan secara pelan-pelan larutan $\mathrm{NaOH}$ $50 \%$ sebanyak $50 \mathrm{ml}$ yang sudah didinginkan dalam almari es. Setelah itu labu Kjeldahl segera dipasang pada alat destilasi. Setelah itu labu Kjeldahl dipanaskan perlahan-lahan sampai lapisan dua cairan tercampur, panaskan lagi dengan cepat sampai mendidih. Destilat ditampung dalam erlenmeyer yang telah diisi dengan $50 \mathrm{ml}$ larutan standart $\mathrm{HCl} 0,1 \mathrm{~N}$ dengan 5 tetes indikator 
metil merah. Destilasi ini dilakukan sampai destilat yang tertampung sebanyak $75 \mathrm{ml}$. Destilat yang diperoleh kemudian dititrasi dengan larutan standart $\mathrm{NaOH} 0,1 \mathrm{~N}$ sampai berwarna kuning. Dibuat juga larutan blanko dengan menggantikan bahan dengan akuades, kemudian lakukan destilasi dan titrasi seperti pada bahan contoh. Kadar protein dihitung dengan cara menghitung \% Nitrogen total dan \% Nitrogen

\section{Analisis kadar abu.}

Setelah contoh bahan tanaman yang akan dihitung kadar abunya dibersihkan dari segala kotoran yang melekat lalu dikeringkan dalam oven atau sinar matahari sampai bahan memungkinkan untuk dugiling dengan Arthur Thomas Mill hingga halus sehingga bahan yang sudah digiling dapat dilalukan dalam ayakan 40 mesh dan disimpan untuk kemudian dianalisis .

\section{HASIL DAN PEMBAHASAN \\ a. Kadar protein tanaman}

Dari hasil pengamatan dan analisis besarnya kadar protein dan abu tanaman alfalfa (Medicago sativa L) akibat pemberian pupuk Biorisa-02 dapat dikemukakan pada Tabel-1 dan Tabel-2 dibawah ini

Tabel-1. Kandungan protein tanaman alfalfa ( medicago sativa $\mathrm{L}$ ) setelah pemupukan Biorisa - 02.

\begin{tabular}{|c|c|c|c|c|c|c|c|}
\hline \multirow{2}{*}{$\begin{array}{l}\mathbf{N} \\
\mathbf{0}\end{array}$} & \multirow{2}{*}{$\begin{array}{l}\text { Dosis } \\
\text { Pemberian } \\
\text { Biorisa-02 }\end{array}$} & \multicolumn{6}{|c|}{ Kandungan protein tanaman ( $\mathrm{mg} / 100 \mathrm{gr}$ ) } \\
\hline & & 1 & 2 & 3 & 4 & 5 & $\begin{array}{l}\text { Rata- } \\
\text { Rata }\end{array}$ \\
\hline 1 & $0 \quad \operatorname{tabl} / \tan$ & 17,65 & 19,81 & 18,06 & 21,11 & 20,69 & $18.264 \mathrm{a}$ \\
\hline 2 & 0,5 tablt/tan & 17,80 & 18,90 & 20,52 & 17,71 & 17,43 & $18,472 \mathrm{a}$ \\
\hline 3 & 1,0 tablt/tan & 19,63 & 20,79 & 22,95 & 19,73 & 20,83 & $20,786 \mathrm{~b}$ \\
\hline 4 & 1,5 tablt $/ \tan$ & 20,00 & 20,32 & 20,12 & 19,38 & 21,59 & $20,82 \mathrm{~b}$ \\
\hline 5 & 2 tablt $/ \tan$ & 19,94 & 21,53 & 21,91 & 22,99 & 22,86 & $21,828 \mathrm{c}$ \\
\hline
\end{tabular}

Keterangan: Angka pada kolom sama dan diikuti oleh huruf kecil yang sama menunjukkan perlakuan yang berbeda tidak nyata dalam uji Duncan pada taraf signifikasi 5\%.

Dari Tabel-1 nampak bahwa dengan bertambahnya konsentrasi biorisa yang diberikan akan menambah tinggi kadar protein tanaman Medicago sativa meskipun pemupukan biorisa dengan konsentrasi 0,5 tablet/tanaman (18,472 $\mathrm{mg} / 100 \mathrm{~g}$ ) berbeda tidak nyata dengan kontrol
$(18,264 \mathrm{mg} / 100 \mathrm{gr})$ dan pemberian biorisa 1,0 tblt/tan juga memberikan kenaikan kadar protein $(20,786 \mathrm{mg} / 100 \mathrm{gr})$ yang berbeda tidak nyata dengan pemberian biorisa 1,5 tblt/tan (20,82 $\mathrm{mg} /$ $100 \mathrm{~g}$ ) dalam uji Duncan(s pada taraf signifikasi 5 $\%$. Sementara itu pemberian pupuk dengan biorisa berkonsentrasi 2,5 tablet/tanaman memberikan kenaikan kandungan protein yang terbesar dibandingkan dengan pemberian bioriza pada tanaman kontrol (18,264 gr/100 gr).

Pemberian pupuk biorisa berkonsentrasi 2 tablet/tanaman ternyata menyebabkan kadar protein tanaman yang paling tinggi $(21,828$ $\mathrm{mg} / 100$ gr) dibandingkan dengan pemberian berkadar lainnya, Hal ini diduga bahwa dengan pemberian biorisa berkonsentrasi 2 tablet/tanaman akan mampu menyebabkan tanaman Medicago sativa $\mathrm{L}$ menyerap lebih baik unsur-unsur hara sehingga sintesis unsur hara terhadap nutrien menjadi lebih baik. Uhadhasya (1998 dalam Subiksa 2002) menyatakan bahwa cendawan yang terkandung dalam biorisa akan menghasilkan senyawa yang mirip dengan glikoprotein yang sangat erat kaitannya dengan kemampuan agregat yang pada akhirnya meningkatkan kemampuan menyerap air dan unsur hara. Happy Widiastyuti $\mathrm{H}$ $d k k ., \quad 2005$ menyatakan bahwa dengan bertambahnya serapan unsur hara akibat pemupukan mikoriza akan bertambah pula naiknya aktivitas penyerapan unsur hara dalam tanah baik yang disebabkan oleh kenaikan serapan unsur $\mathrm{N}$, $\mathrm{K}$ dan unsur $\mathrm{S}$ yang larut dalam air.

Disamping naiknya serapan unsur hara $\mathrm{N}$, $\mathrm{K}$, dan $\mathrm{S}$; pemupukan dengan biorisa-02 dapat pula disebabkan karena hifa dari biorisa-02 ini akan menambah pengeluaran ensim fosfatase.. Ensim phosphatase ini mampu melepaskan unsur $\mathrm{P}$ dari ikatan-ikatan yang spesifik sehingga ketersediaan unsur $\mathrm{P}$ menjadi lebih banyak dan mudah diserap oleh tanaman (Hyman, 1970 ).

Tidak kalah pentingnya dalam sintesis protein ini adalah ketersediaan unsur Nitrogen didalam media tumbuh tanaman. Baik sebagai asam amino, protein, amida klorofil dan tersedianya basa nitrogen terutama purin dan pirimidin (Salisbury \& Ross, 1992). Pemupukan dengan biorisa-02 diduga mampu pula meningkatkan serapan unsur nitrat, amonium, dan nitrogen tanamanSalisbury \& Ross, 1992; Subiksa 
2002). Dengan adanya kenaikan unsur hara akibat pemberian biorisa-02 ini maka akan terjadi kenaikan penyerapan unsur yang berakibat terjadinya sintesais protein meningkat sehingga terjadi pula kenaikan protein di dalam jaringan tumbuhan.

Pemberian biorisa-02 pada dosis 1 tablet/tanaman terutama pada dosis 2 tablet/tanaman diperkirakan mampu nenaikkan serapan nutrien bagi tanaman terutama mampu menaikkan serapan hara dan air bagi hifa eksternal biorisa (Bintari \& Rudiyatmi 2006 ). Serapan air dan hara yang lebih besar oleh biorisa ini juga akan meningkatkann serapan unsur N.,K dan S yang larut dalam air. Disamping itu pemupukan biorisa-02 pada dosis 2 tablet/tanaman diduga karena hifa biorisa juga akan lebih mampu mengeluarkan ensim fosfatase yang mampu melepaskan P dari ikatan-ikatan spesifik sehingga akan membantu tersedianya unsur $\mathrm{P}$ bagi tanaman (Bintari \& Rudiyatmi, 2006 ; Subiksa 2002). Unsur ini yang kemudian terlibat dalam sintsis lebih lanjut untuk kemudian di ubah menjadi protein pada metabolisme lebih lanjut.

Mengingat tanaman alfalfa (Medicago sativa $\mathrm{L}$ ) adalah tanaman yang dapat membentuk bintil akar (Anonim-a ; Anonim-d) maka pemupukan biorisa berkonsentrasi 2 tablet/tanaman . Pemupukan biorisa-02 diduga mampu menaikkan interaksi sinergis antara biorisa-02, sehingga tanaman Medicago sativa akan mampumenambah bintil akar yang terbentuk ; sehingga menambah ensim yang dikeluarkan oleh biorisa -02 yang dalam keadaan yang tidak tersedia diubah kedalam bentuk yang tersedia yaitu diantaranya hara N. P, K dan $\mathrm{Zn}$ sehingga meningkatkan asimilasi protein tanaman (Bintari \& Rudiyatmi 1990). Masih oleh penulis yang sama dikatakan bahwa terdapat peningkatan pertumbuhan Tribulus terrestris L yang dipupuk dengan mikorisa. Hal ini dikatakan oleh semakin tinggi infeksi mikorisa maka semakin tinggi kemampuan tanaman untuk menyerap $\mathrm{P}$ dari tanah ke jaringan tanaman (Suciatmih 1996). Hal ini sesuai dengan pendapat Palealu J ( 2003 ) yang mengatakan bahwa pemberian MVA akan berpengaruh dan mempengaruhi berat kering, protein kasar dan kadar fosfor tanaman sorghum (Sorgum bicolor, L Moench
Dalam sintsisnya, protein terbentuk dari unsur- unsur hara seperti $\mathrm{C}, \mathrm{H}, \mathrm{O}, \mathrm{N}, \mathrm{S}, \mathrm{P}$, dan K yang dalam sintesisnya nanti akan diubah menjadi asam nukleat, hormon tumbuh dan ensim di dalam tubuh tanaman, dan pada akhirnya akan berperanan di dalam aktivitas sel sehari-hari seperti proses pembelahan maupun menggantikan sel yang sudah rusak atau tua. Hal ini sesuai dengan pendapat Palealu J (2003) yang mengatakan bahwa pemberian MVA akan berpengaruh dan mempengaruhi berat kering, protein kasar dan kadar fosfor tanaman sorghum ( Sorgum bicolor, L Moench)

Alfalfa (Medicago sativa L) merupakan tanaman polong yang dapat membentuk bintil akar. Pemberian biorisa-02 berkadar 2 tablet/tanaman pada Medicago sp diduga akan mempercepat pembentukan bintil akar tanaman ini. Bintil akar yang terbentuk pada tanaman Medicago sp ini lazimnya mengandung beberapa ribu bakteroid. Bakteroid biasanya berkelompok di dalam sitoplasma yang dikelilingi oleh suatu sekat yang disebut membran peribakteroid. Diluar ruang peribakteroid ini terdapat leghemoglobin yang berwarna merah dan menempel sebagai gugus prostetik akan membentuk senyawa nitrogen utama yaitu asparagin dan ureida yang nantinya akan dirombak menjadi asam amino, amida dan protein (Winkler 1988 dalam Salisbury \& Ross, 1995) . dengan meningkatnya pemberian biorisa-02 ini akan memacu sintesis asparagin dan ureida yang akan menyebabkan naiknya protein yang disintesis tanaman Medicago sativa $\mathrm{L}$

Hyman (1988 ; Suciatmih 1996) akar mikorisa atau hifa jamur ini dapat menyerap unsur $P$ dari larutan tanah, pada konsentrasi dimana akar tidak bermikorisa tidak dapat menjangkaunya, meskipun dengan rambut akar yang berlimpah. Diameter hifa jamur yang relatif kecil yaitu $2-5$ ųm akan mudah menembus pori pori-pori tanah yang tidak bisa dimasuki rambut akar yang diameternya relatif besar.

Hipotesis yang ke dua yaitu dengan naiknya dosis biorisa -02 yang diberikan pada tanaman, adalah dengan pemberian pupuk biorisa02 akan terjadi peningkatan pembentukan bintil akar. Tanaman Medicago sativa merupakan tanaman polongan yang mampu membentuk bintil akar (Palealu, 2003 ; Anonim-b) maka dengan 
penambahan Rhisobium biorisa-02 akan memacu penyerapan $\mathrm{N}$ dari tanah baik dalam bentuk nitrat, amonia atau amonium, nitrogen organik dan molekul nitrogen. (Suciatmih, 1996). Nitrat atau amonium. Dalam bentuk ion $\mathrm{NO}_{3}^{--}$dari tanah akan diangkut dari akar ke bagian atas tumbuhan melalui silem dan mula mula akan direduksi terlebih dahulu menjadi amonium atau amonia, baru biubah menjadi senyawa $\mathrm{N}^{`}$ organik. Adapun mekanisme reduksi nitrat menjadi amonium atau amonia dan senyawa organik menurut (Salisbury \& Ross, 1992 ) adalah sebagai berikut (1) Perubahan nitrat $\left(\mathrm{NO}_{3}^{--}\right)$menjadi nitrit $\left(\mathrm{NO}_{3}{ }^{--}\right)$ oleh ensim nitrat reduktase (2). Perubahan nitrit menjadi hiponitrit oleh ensim nitrit reduktase (3) Perubahan niponitrit menjadi hidroksilamin dan (4) Perubahan hidroksilamin menjadi amonia oleh ensim hidroksilamin reduktase; dalam bentuk amonia ini karena merupakan senyawa yang toksik maka akan segera mengalami sintesis lebih lanjut menjadi senyawa- senyawa organik baik yang berupa asam amino, amida maupun senyawa karbamil fosfat, dengan kenaikkan sintesisi senyawa ini akan menambah protein sebagai hasil sintesis

Peningkatan protein Medicago akibat pemupukan bioriza-02 disebabkan karena adanya peningkatan metabolisme menjadi ureida dan sitrullin. (Vickery \& Vickery 1981). Menurut Walsh $d k k$. (1989 dan Winkler $d k k, 1988$ dalam Salisbury \& Ross, 1992) merupakan asam amino utama dalam bentuk nitrogen dan dominan pada tumbuhan alfalfa (M. Sativa) adalah asparagin; sedang Schubert, (1986) mengatakan bahwa selain asparagin asam amino yang mula mula terbentuk dalam sintesis ini adalah ureida dan sitrullin. Dengan naiknya serapan unsur ini maka akan menambah pula metabolisme protein di dalam tumbuhan ini, sehingga kadar protein tanaman akan meningkat

\section{b. Kadar abu}

Terhadap kadar abu tanaman Medicago sativa $\mathrm{L}$ setelah pemberian pupuk dengan biorisa 02 dapat dilihat pada tabel-2 di bawah ini

Tabel-2. Kandungan abu tanaman alfalfa ( medicago sativa $\mathrm{L}$ ) setelah pemupukan Biorisa-02.

\begin{tabular}{|c|c|c|c|c|c|c|c|}
\hline & \multirow{2}{*}{$\begin{array}{l}\text { Dosis } \\
\text { Pemberian } \\
\text { Biorisa-02 }\end{array}$} & \multicolumn{5}{|c|}{ Kandungan abu tanaman pot ke : } & \multirow[b]{2}{*}{ Rata-rata } \\
\hline $\begin{array}{l}\text { N } \\
\text { a }\end{array}$ & & 1 & 2 & 3 & 4 & 5 & \\
\hline 1 & $0 \mathrm{tabl} / \mathrm{tan}$ & 78,34 & 78,34 & 76,71 & 78,34 & 76,71 & $69,688 \mathrm{a}$ \\
\hline 2 & 0,5 tablt $/ \tan$ & 76,59 & 77,59 & 64,87 & 64,87 & 74,49 & $71,982 \mathrm{a}$ \\
\hline 3 & 1,0 tablt $/ \tan$ & 86,76 & 74,49 & 76,00 & 64,87 & 64,24 & $73,272 \mathrm{a}$ \\
\hline 4 & 1,5 tablt/tan & 77,90 & 77,66 & 77,17 & 76,79 & 78,85 & 77,674 a \\
\hline 5 & 2 tabltt/tan. & 74,88 & 74,98 & 78,62 & 78,91 & 78,81 & $77,24 \mathrm{a}$ \\
\hline \multicolumn{2}{|c|}{ Keterangan : } & \multicolumn{6}{|c|}{$\begin{array}{l}\text { Angka pada kolom sama dan } \\
\text { diikuti oleh huruf kecil yang sama } \\
\text { menunjukkan perlakuan yang } \\
\text { berbeda tidak nyata dalam uji } \\
\text { Duncan pada taraf signifikasi } 5 \% \text {. }\end{array}$} \\
\hline
\end{tabular}

Dari Tabel-2 nampak bahwa dengan pemupukan biorisa-02 sampai dengan pemupukan bioruisa-02 berkadar 2 tablet/tanaman memberikan perbedaan terhadap kadar abu tanaman yang terbentuk walaupun pada uji statistik Duncan-s 5 $\%$ memberikan hasil yang berbeda tidak nyata terhadap kandungan abu tanaman. Perbedaan kandungan abu pada tanaman $M$. Sativa L ini diduga karena tanaman alfalfa yang diberi dengan pemupukan biorisa-02 pemberian pupuk biorisa02 diduga tidak mampu menaikkan konsentrasi hara di dalam jaringan tanaman. Meskipun pemupukan biorisa-02 ii mampu menaikkan kadar protein tanaman $M$. Sativa; namun kuat dugaannya bahwa kenaikkan protein ini belum mampu menaikkan konsentrasi hara di dalam jaringan tanaman.

\section{KESIMPULAN}

Dari penelitian kandungan protein dan abu tanaman alfalfa (Medicago sativa L) setelah pemupukan biorisa-02 dapat disimpulkan :

1. Semakin tinggi dosis biorisa-02 yang diberikan akan menyebabkan kenaikkan kadar klorofil tanaman Medicago sativa $\mathrm{L}$

2. Pemberian biorisa-02 berkonsentrasi 1 tablet / tanaman akan menaikkan kadar klorofil tanaman meskipun kadar klorofil ini berbeda tidak nyata dengan pemberian biorisa berkonsentrasi 1,5 tablet / tanaman.

3. Pemupukan dengan konsentrasi biorisa 2 tablet/tanaman memberikan kenaikkan klorofil yang paling nyata.

4. Pemupukan biorisa-02 pada tanaman memberikan perbedaan respons yang tidak nyata dalam penambahan kadar abu tumbuhan. 


\section{DAFTAR PUSTAKA}

Agustina, B; Bachrein, S. Soenartiningsih,.M.R. 1977. Interaksi P dan Karbohidrat Terhadap Pembentukan Kolonisasi Mikoriza Vasikular Arbuskular (MVA) Pada Tanaman Jagung. Penelitian Pertanian Tanaman Pangan 15. hal : $18-23$.

Annim,-a, 2006. Biorizza 92 K. BALITBU Solok, Sumatera Barat

Anonim-b, 2004.htpp: //www.nature.com / bjp / new site / cgi / content / abstract

Anonim-c, $2004 \quad: \quad$ htpp : www.nature.com/nchalbio/index

Anonim-d. 2002 Alfalfa King ${ }^{\text {tm }}$. All rights reserved. | Terms of Use | Privacy Statement Site Disclaimer: Any and all information given on this web site is to best of Alfalfa King's knowledge

Baiq.A.H.; mudji.S. Pertumbuhan dan Hasil cabai merah ( Capsicum annum ) Pada Andisol Yang Diberi Mikoriza, Pupuk Fosfor Dan Zat pengatur Tumbuh. WWW. Pertumbuhan $\% \quad 2520 \quad \% \quad$ dan $\% 2520$ hasil \%2520cabai\%2520merah.pdf

Bintari, S, \& Rudyatmi, E. 2006. Pertumbuhan, kandungan khlorofil, lemak, protein, Serat kasar dan abu Pada Defoliasi Pertama Alfalfa ( Medicago sativa L ) Akibat Penggunaan Mikoriza. Fakultas Matematika Dan Ilmu Pengetahuan Alam Jurusan Biologi. Universitas Negeri Semarang (UNNES) Tahun 2006.

Happy Widiastyuti; Sukarno N, Darusman L.K. Goenadi.D.; Smith.S; Guhardja.E. 2005. Penggunaan Spora Cendawan Mikoriza Arbuskula Sebagai Inokulum Untuk Meningkatkan Pertumbuhan dan Serapan Hara Bibit Kelapa Sawit. Menara Perkebunan. 2005.73(1) 26 - 34

Harborne.J.B.1987. Metode Fitokimia. Penuntun Cara Modern Menganalisis Tumbuhan. Terbitan kedua. Penerbit ITB Bandung. 1987.

Hayman. D.S. 1975. Plant Growth Response to Vesicular Arbuscular Mycorriza. VI. Effect of Light and Temperatur.New Phytol. Moase. B. 1981. Vasculer Arbuscular Mycorrhizal Research for Tropical Agriculture. Res. Bull. Hawai Ins. Trop. Agric. Hum. Resour. 192: 82.

Laila.I.N. 2005. Alfalfa Tanaman Tertua yang Kini Mulai Dikembangkan di Semarang. Jawa Pos Selasa 1 Maret 2005.

Palealu, Johanis J. 2003. Biofertilisasi Mikoriza Vascular Arbuscular dan Pupuk organik Pada Sorghum ( Sorgum bicolor, L Moench ) Di Lahan Marginal Perkebunan kelapa ( Cocos nucifera 1 ) 2003. jiptunair-gdl-s32003-pelealu2c-827-mikoriza - Airlangga University Library - GDL 4_0.htm

Salisbury F.B. \& Ross.C.W.1992. Terjemahan Lukman \& Sumaryono 1995. Fisiologi Tumbuhan. Jilid I,II dan III. Edisi ke empat. Penerbit ITB. Bandung.

Stocmal A, Piacente S, Pizza C, De Riccadis F, Leitz R dan Oleszek W. 2001. Alfalfa (Medicago sativa L ) Flavonoids. 1. Apigenin and Luteolin glycosides from aerial parts. J. Agric Food Chem. Entrez PubMed.

Suciatmih.1996. Bagaimana Jamur MikorizaArbuscular Meningkatkan Ketersediaan Dan Pengambilan Fosfor. Baaslitbang mikrobiologi, Puslitbang Biologi LIPI. Warta Biotek Vol. 10 No. 4 . Desember 1996

Subiksa. I.G.M. 2002. Pemanfaatan Mikorisa Untuk Penanggulangan Lahan kritis. IPB Bogor.

Sudarmaji. S, Haryono, B, Suhardi. 1984. Prosedur Analisis Bahan Makanan dan Pertanian. Ed. Ketiga. Liberty Yogyakarta.

Vickery.B \& Vickery. 1981. Secondary Plant Metabolism. University Park Press. Baltimore.

Yuli, S. 2004. Klorofil. Obat alami. Suara Merdeka, 7 September 2004. 